\title{
Health and consumption of health care and social service among old migrants in Sweden
}

Björn Albin and Marie Albertsson School of Health Sciences and Social Work, Växjö University, Sweden Jan Ekberg School of Management and Economics, Växjö University, Sweden and Katarina Hjelm Department of Community Medicine, University of Lund and School of Health Sciences and Social Work, Växjö University, Sweden

\begin{abstract}
Due to migration, an increasing number of the elderly in Sweden will be foreignborn, 'old migrants'. Old migrants will need help from society with health care and social service. Migration may influence people's health and thus also their consumption of health care and social service. The aim of the present study was to discuss migration and health with the focus on old migrants by a review of literature, and to describe the pattern of health care and social service consumption among old migrants living in Sweden, studying whether there were any differences compared with old people born in Sweden. The results showed that there is a lack of data describing old migrants' health. Available data indicate poorer self-rated health, more chronic illness and impaired mobility capacity. There are some Swedish studies describing morbidity and mortality among migrants in Sweden. These are consistent: migrants have more health problems in general and migrants from the Nordic countries have a higher mortality rate. There are no public statistics about old migrants' consumption of health care and social service in Sweden. Some studies show that old migrants consume less than native Swedes. Other studies indicate the same or higher consumption of health care, but lower consumption of social service among migrants. In conclusion, few studies concern health and consumption of health care and social care among old migrants; the results are divergent and there could be several different explanations for dissimilarities, such as migrational background, cultural distance, time of residence, socioeconomic position and adaptation in the new society. Thus, further studies are needed.
\end{abstract}

Key words: health; health care consumption; migration; old migrants; social service consumption

\section{Introduction}

Sweden has an ageing population. The number of people aged 65 years or over has increased during the past century, from $8 \%$ of the population in 1900 to $17.4 \%$ today. Sweden has one of the highest proportions of elderly people of any country in the world today (Berg, 1996; SCB, 2001).

Another change in Swedish society during the last century has been due to international

Address for Correspondence: Björn Albin, School of Health Sciences and Social Work, Växjö University, S-351 95 Växjö, Sweden. Email: bjorn.albin@ivosa.vxu.se migration. In 1950 about 200000 foreign-born persons lived in Sweden. Today the number has increased to slightly more than 1 million (SCB, 2001). Migration has been an important factor for the increase of the total population in Sweden. If no migration had occurred the Swedish population would have stagnated at a level of 7.4 million people, the same level as Sweden had in 1970 (Hjelmskog, 2000). The total population in Sweden today is 8.9 million (SCB, 2001).

Migration patterns to Sweden have changed. Between 1945 and 1970, most migrants came as labour migrants from the Nordic and other European countries. They were recruited by Swedish 
companies as healthy labourers. Migration after 1970 has been dominated by refugees from nonEuropean countries, with the exception of refugees coming from the former Yugoslavia (Bosnia) in the early 1990s (SOU, 1996: 55). They have been forced to leave their countries and have fled from war and persecution.

The migrant population in Sweden is young compared with the native Swedish population. More than $90 \%$ of the migrant population are under 65. Among native Swedes, $81 \%$ of the population are under 65 (SCB, 2001).

The age structure among migrants will adjust to that of the native Swedish population in the long term. In 1970, there were 35000 foreignborn people aged 65 years or over living in Sweden. The number rose to 130000 in 1999 , which means that $8.6 \%$ of all people aged 65 years or over in Sweden are foreign-born. During the 1990s, 15770 persons aged 65 years or more also received Swedish residence permits (Socialstyrelsen, 2000: 4).

Old migrants as a group have received more and more attention both from the Swedish Government and from Swedish researchers. One explanation for this is the demographic change with an increasing number of elderly in the population; another is the Swedish migration policy, which has changed from assimilation to encouraging a multicultural society. A third explanation could be the ambition of Swedish leaders to find the means of integrating migrants. If new forms of social services, adapted to the needs of older migrants, were developed, presumably they would use them. Relatives' responsibility for care would then decrease and they would then have more time to participate in Swedish society (Gaunt, 1996).

It is difficult to be sure what effect migration will have on people's health; both positive and negative influences can occur due to factors such as better access to food or higher exposure to air pollution; there may also be combinations of both positive and negative influences. The degree of adaptation also has a strong influence on the health of the migrant population (Hull, 1979). Migration, whether forced or not, may cause lifestyle changes (new dietary customs, inactivity, etc.), social degradation and psychosocial stress (Hjelm, 1998), which may act as stressors altering the endocrine balance and increasing susceptibility to disease (Cassel, 1974; Selye, 1950) and thus the consumption of health care and social care. In the present study we hypothesized that old migrants have poorer health and higher consumption of health care and social care than old Swedes.

The number of old migrants will increase in Sweden, as described earlier, and as old people they will need help from society with care and social service. Because of this it is interesting to study how old migrants today consume health care and social services and whether their patterns are different from those of native Swedes.

\section{Definition}

\section{The term 'old migrants'}

Conventional meaning attached to 'old migrants' describes people who are 65 years or over and not born in Sweden.

The term came into use in the late 1970s when different government committees investigated questions related to the creation of a Swedish migrant policy. In the final report from one of the committees (Invandrarpolitiska kommittén) the term 'old migrants' was used officially for the first time (SOU, 1984: 58).

During the 1960s the word 'migrant' had replaced 'foreigner', which had become a word with negative connotations. One explanation for the use of the term 'old migrants' in Sweden, according to Gaunt (2002), is the recent Swedish tradition of having a focus on migration and migration policy. Countries with a long tradition of migration have instead had a focus on 'minorities'. In the USA, the focus has been on old people from minority groups constituted by race, language or religion, irrespective of whether they were born in or outside USA. Migrants who belong to the 'white majority' have been of less interest to researchers and policymakers. In England the interest has tended to been concentrated on one minority group, 'black people', which means people from Africa, Pakistan, India, Sri Lanka and the Caribbean. In Australia, the interest has been focused on 'non-English speaking people' and in Israel on old people who have arrived in the country recently. In Israel distinctions are made between persons from East and Central Europe and persons from the Middle East and Africa (Gaunt, 2002). 


\section{Aim of the study}

The aim is to discuss migration and health with a focus on old migrants, by means of a review of literature. A further aim is to describe patterns of health care and social service consumption among old migrants living in Sweden and to see whether there are any differences compared with old people born in Sweden. Health care and social service are defined as stipulated in the Swedish Health and Medical Services Act (SFS, 1982: 763) and in the Social Services Act (SFS, 2001: 453). Old migrants are defined as foreign-born people aged 65 or over.

\section{Results}

The literature review is presented under the following sections: 'Migration and health', 'Old migrants and health', 'Old migrants' consumption of social service', and 'Old migrants' consumption of health care'.

\section{Migration and health}

One way to describe health among migrants is to study the patterns of morbidity and mortality. There are a few international studies with a broad perspective in which morbidity and mortality among all migrants have been studied (Balarajan, 1995-96; Singh and Siahpush, 2001; Strong et al., 1998). These studies show a lower mortality rate for migrants from UK, Ireland, Europe, Asia and other countries than for the native population but also differences between different groups of migrants. Some migrants coming from specific countries have a higher mortality rate from special causes of death (Singh and Siahpush, 2001; Strong et al., 1998). There are some Swedish studies describing morbidity and mortality among migrants in Sweden. To a certain degree they are unanimous: migrants have more health problems in general and migrants from the Nordic countries have a higher mortality rate.

Migrants born in one of the Nordic countries, Finland, have a higher mortality rate in diseases related to alcohol, cardiovascular diseases (CVD), and cancer of the stomach and lungs (Weitoft et al., 1998). Migrants born in Finland especially have a higher mortality rate from CVD
(Sundquist and Johansson, 1997). Migrants born outside the Nordic countries have a higher mortality rate from lung cancer (Weitoft et al., 1998).

A report from the National Board of Health and Welfare shows that migrants (from the former Yugoslavia, Finland, Norway, Denmark, Germany, Poland, Hungary, Eastern Europe, Turkey, Chile and Iran) have poorer self-rated health than Swedes of the same age, of the same sex and at the same socioeconomic level (Socialstyrelsen, 1995). Health in migrant groups is also a topic in a government committee report called 'Welfare report for the 1990s' (Välfärdsbokslut för 1990-talet), in which self-rated health is shown to be lower among migrants than among the native Swedish population. Symptoms, such as anxiety and fear, are more common (SOU, 2001: 79).

\section{Old migrants and health}

Very few studies have dealt with health among old migrants in Sweden. Silveira (2001) states in her dissertation that old migrants living in Gothenburg have the same mortality patterns as native Swedes but poorer self-rated health. Other studies have reported impaired working capacity and impaired mobility among foreign born people in the age group 55 to 74 years (Pudaric et al., 1998). Differences in self-rated health between foreign born and native Swedes can be of mainly subjective significance (Waern and Steen, 1995). An increased risk of CVD has been reported among old migrants (Pudaric et al., 2000). The rate of long-term illness is stated to be the same for both old migrants and old native Swedes (SOU, 2001: 79). Waern and Steen (1995) have studied health among old migrants and found differences in self-rated health compared with native Swedes. Old migrants had poorer self-rated health but the objective health controlled by means of medical examination was the same.

The National Institute of Public Health in Sweden states that there is a lack of data describing old migrants' health. Available data for this group indicate poorer self-rated health, more chronic illness and impaired mobility capacity. Old migrants have more contact with medical doctors but less contact with dentists than have native Swedes (Äldreberedningen, 1998). 


\section{Old migrants' consumption of social service}

In Sweden social services for elderly is a responsibility for the local authorities. It is stated in the Swedish Social Services Act and the basic principle is that all citizens are of equal value and have the same right to social and financial security, care and assistance (SFS, 2001: 453). A national inquiry in 1991 by the National Board of Health and Welfare and the Swedish Migration Board reported that very little had been done to meet the needs of old migrants. The local authorities had low level of preparedness, 24 of 284 local authorities had made surveys regarding the needs of old migrants and only 16 local authorities had written information about their elderly care services in different languages (Socialstyrelsen, 1991). There are no public statistics about old migrants' consumption of health care and social service in Sweden. Small-scale local studies show that old migrants in particular groups consume less than native Swedes.

A study by the National Board of Health and Welfare collected data from three Swedish counties and reported a difference in consumption between old migrants and old native Swedes in two of the largest local authorities. In the age group 65 years or over (Table 1), $17.4 \%$ of native Swedes used elderly care, but only $10.4 \%$ of the old migrants did the same. Two migrant groups had a very low consumption of elderly care,

Table 1 Foreign-born people in Gothenburg and Halmstad aged 65 or over with social service or special living arrangements (December 1994)

\begin{tabular}{lcl}
\hline Country of birth & $\begin{array}{l}\text { Number of } \\
\text { foreign-born } \\
\text { aged 65 or over }\end{array}$ & $\begin{array}{l}\text { Percentage of } \\
\text { people using } \\
\text { elderly care services }\end{array}$ \\
\hline Finland & 124 & 11.0 \\
Norway/Denmark & 265 & 12.6 \\
Yugoslavia & 16 & 3.8 \\
Poland & 48 & 10.8 \\
Germany & 90 & 15.1 \\
Iran & 9 & 2.8 \\
Turkey & 12 & 6.7 \\
Other countries & 261 & 8.7 \\
All foreign-born & 825 & 10.4 \\
Sweden & 12401 & 17.2 \\
\hline
\end{tabular}

Source: Erikson, 1996 migrants from Yugoslavia 3.8\% and migrants from Iran 2.8\% (Eriksson, 1996).

Altvall (2000) refers to a study in Stockholm regarding old people and consumption of elderly care provided by the local authorities. This study found small differences in consumption between native Swedes and migrants born in the Nordic and west European countries. However, there were major differences between old people born in west European and non-west European countries. In the age group 85 to 89 years, $50 \%$ of Swedes and migrants born in a west European country had social service from the local authority, while among migrants from a non-European country the percentage was 25\% (Altvall, 2000). Songur (2002) compared old migrants from the Middle East living in Stockholm, Berlin and London. The study was based on a questionnaire and interviews with 150 immigrants 55 years or more from three ethnical groups (Turks, Kurds and Assyrians). The old migrants in Stockholm described their health as bad, with mobility problems particularly, but they felt their access to health care was good. Informal care, care from relatives and friends, was common but the migrants in Stockholm had better access to transportation service and social service than the migrants in London and Berlin. Elderly care in Stockholm has a lack of day centres and many of the old migrants felt isolated.

\section{Old migrants' consumption of health care}

A study using data from interviews with persons drawn from the Swedish population registry shows that more foreign-born people than native Swedes have felt a need to consult the health care sector but have not done so (Westerling, 2001).

Ekman et al. (1998) have studied the consumption of health care and social service among old migrants born in Finland and Iran. Migrants from Iran consumed a great deal of health care and had a positive view of treatment with medication. They were not positive about receiving rehabilitation and post-hospital care. The group of old Finnish-born migrants wished for more public elderly care, but wanted this care to be provided by people with the same cultural background. The most important thing was that the providers used the Finnish language. No findings in the study by Waern and Steen (1995) indicated a higher consumption of health care. 
Table 2 Percentage who have been in contact with or visited a physician in the last three months

\begin{tabular}{lll}
\hline Age & Contact & Visit \\
\hline $16-24$ & 39.8 & 25.1 \\
$25-34$ & 37.6 & 24.5 \\
$35-44$ & 36.7 & 22.9 \\
$45-54$ & 42.4 & 26.1 \\
$55-64$ & 49.0 & 31.3 \\
$65-74$ & 45.8 & 28.0 \\
$75-84$ & 52.1 & 36.30 \\
\hline
\end{tabular}

Source: SOU, 2000: 38.

A government report describes how the number of contacts with medical doctors increases with increasing age (Table 2; SOU, 2000: 38). The report also shows that foreign-born people have more contacts with medical doctors than people born in Sweden, but they do not use medicines as much as native Swedes. More foreign-born people have refrained from contact with a doctor despite having felt a need for it (Table 3; SOU, 2000: 38).

A study of adult diabetic patients of whom two-thirds were 65 years or over shows no major differences between foreign-born people and native Swedes in the consumption of health care. The only significant difference was a higher use of home care from public authorities in the Swedish-born group, although the need was not higher (Hjelm et al., 1997).

\section{Discussion}

This article is the first, as far as we know, to summarize the present knowledge about health and health care and social service consumption among old migrants in Sweden. Major findings of the literature review are that there are differences

Table 3 Percentage who have been in contact with, visited or have refrained from a visit to a doctor in the last three months by country of birth

\begin{tabular}{llll}
\hline $\begin{array}{l}\text { Country of } \\
\text { birth }\end{array}$ & Contact & Visit & $\begin{array}{l}\text { Refrained } \\
\text { from visit }\end{array}$ \\
\hline $\begin{array}{l}\text { Sweden } \\
\text { Foreign-born }\end{array}$ & 41.7 & 26.3 & 10.0 \\
\hline
\end{tabular}

Source: SOU, 2000: 38. in health between old migrants and old native Swedes, with self-rated health especially being poorer among migrants. There are also differences in consumption of health care and social service between the two groups. Health care consumption is the same or higher, but consumption of social service is lower among migrants. However, there is no clear pattern and thus the hypothesis stated was neither confirmed nor disproved by the results of this literature review. Several different factors such as social position, cultural background, migrational background, time of residence and cultural distance can explain the differences in health and health care and social service consumption.

\section{Factors influencing the consumption of health and social service}

A public health report from the county of Stockholm has focused on health care consumption and use of the national social insurance system among migrants (Ekblad et al., 1998). The report shows that migration may explain how health care and social insurance are used, but is not a sufficient explanation. It is a disadvantage to be a migrant, but there are great differences between different groups of migrants. Poor health can be better explained by other factors such as low level of education, unemployment, segregation, low-status work and difficulties in speaking the language (Ekblad et al., 1998). Similar results are presented in a dissertation about foreign-born diabetic patients. Low social position had a stronger influence on both self-rated and objective health than country of birth (Hjelm, 1998).

Different studies have studied both self-rated and objective health. Small differences have been found in objective health status between immigrants and native Swedes but the self-rated health is different (Waern and Steen, 1995). Self-rated health is influenced by cultural background and can affect self-care and use of health care (Hjelm, 1998). Poorer health could contradict a 'healthy migrant effect', which sees migrants and especially labour migrants as a healthier sample than the population from which they migrate (Marmot et al., 1984). Thus there are studies indicating that self-rating of health can be affected by cultural background so that it is not a reliable 
measure to use when comparing groups with different cultural backgrounds (Jylha et al., 1998).

The pattern of migration to Sweden has changed from labour migration to migration of refugees. This can have an influence on health pattern and also on the health care and social service sector in the future. Old migrants today are mainly people who have come as labour migrants from countries in Europe with a short cultural distance. People from non-European countries with a longer cultural distance will dominate the future group of old migrants. The migration background will be different and traumatic experiences more common. Factors such as time of stay and cultural distance may influence the consumption of health care and social service (Hjelm, 1998).

Early experiences of health care and the social service system in the country of birth can lead to a different approach towards solving health care and social service problems among migrants. It can be seen as more natural to receive help from the informal sector (family, neighbours and relatives) than to turn to the professional sector (public health care and social service) (Hjelm, 1999). This may be one explanation as to why public care is used less by migrants. Networks, like family, relatives and neighbours, can be used as resources when health care or social care problems are to be solved. Östergren (2001) sees the social capital as an important aspect. Pessar highlights other aspects of the family and the importance of the social environment in connection with migration, and she also discusses gender aspects, the small household and social networks. Pessar believes it can sometimes be a necessity for migrants to maintain very strong family ties (Pessar in Hirschman et al., 1999).

\section{Factors influencing access to health care and social service}

The studies that have been found show that certain groups of foreign-born people, especially people born outside Europe, could have a higher consumption of more acute health care and a lower consumption of elderly care (Äldreberedningen, 1998; Altvall, 2000; Socialstyrelsen, 1995). This is in accord with migrants having poorer self-rated health and hence a need for more contacts with the health care sector. It could also indicate that the health care problems are not the type of problems normally solved by elderly care. A higher consumption of acute health care and lower consumption of elderly care could be explained by the better availability of health care than of elderly care. It is possible that health care, with its clearly defined roles such as doctors and nurses, is more 'universal' and easier to recognize than the structure of elderly care. The structure of elderly care in Sweden can differ by area and between different local authorities.

Few studies have examined what needs old foreign-born people themselves express and what kind of elderly care they would like. Because of this it is difficult to be sure whether the elderly care we have today is relevant and able to meet the needs of old migrants. Swedish elderly care might be too much based on a Swedish 'model', and parts of it may be of no interest to old migrants.

Another explanation could be changes in Swedish elderly care. The local authorities are more restrictive today about giving help and support to elderly people. A smaller number of old people receive help today compared with the situation in the 1960s and 1970s. The smaller number could be a sign of better health - fewer people need help - but it could also as be interpreted as showing that not all will get the help they need (Eliasson-Lappalainen and Szebehely, 1996).

Since the 1980s stricter priorities have been made regarding the use of resources in the health care and social care sectors. The number of beds and the mean length of stay in hospital have been reduced (SOU, 2000: 38; Westerling, 2001).

In the Health and Medical Services Act good health and care on equal terms for the entire population are stipulated as goals (SFS, 1982: 763). The Swedish health care system, according to Westerling (2001), has provided good access for different groups in the population to good care when compared with other countries. What is of importance today is to study the effects of the changes that have been made during the last 10 years. Have the changes had consequences for the possibilities to provide good care on equal terms? No studies have been found focusing on how the changes have affected the migrants and their ability to access health care and social service. 
An important factor in access ability is the possibility to communicate. Staff can experience difficulties in care situations with immigrants because communication is limited (Hjelm, 1998). It is also reasonable to assume that language difficulties can limit the ability of migrants to establish contact and obtain a correct assessment of their needs.

One question that has been discussed in some studies is whether special living arrangements adjusted to old migrants should be developed. According to Ronström (1996), Sweden has a tradition of interpreting 'equality' as giving everyone the same care and service and not looking at their background. Language aspects could be an argument for special solutions and arrangements. Special homes for special migrant groups, 'ethnic housing', could be positive but could also lead to segregation (Dalenstam, 1999).

\section{Methodological discussion}

As stated earlier, the subject area of old migrants and their consumption of health care and social service has not been studied to any great extent. Too few studies have been carried out to give a homogeneous picture. A great difficulty is that statistical data are missing with regard to migrants and health care and social service consumption. Statistics Sweden presents only statistical data on foreign-born people in different age groups and the National Board of Health and Welfare presents statistical data on health care and social service in different age groups at national and local level. Some data about consumption of hospital care are available from the Centre for Epidemiology at the National Board of Health and Welfare. No study has been found using this information source. Every year Statistics Sweden interviews 7500 persons drawn from the Swedish population registry and gathers data about living conditions in Sweden. This statistical data gives a general view and can be used as a starting point for further and more detailed studies.

In most studies in Sweden the term 'migrant' is defined as 'foreign-born'. This has an advantage when statistical data produced in Sweden are used because the Swedish population registry uses the same definition. A problem in the Swedish population registry is a shortage of registration of addresses for old migrants. Many of them are living with their children. Others may have returned to their home countries without changing address. The problems of data registration in the Swedish population registry are discussed by Ekberg in one of his articles (1995).

The only information the term 'old migrant' gives is that a person is foreign-born but living in Sweden and is 65 years or over. The term says nothing about home country, socioeconomic level, reasons for the migration, living conditions on arrival in Sweden or how long the migrant has lived in Sweden.

There could be several different explanations for differences in health, health care and social care consumption between old migrants and old native Swedes. Thus further studies are needed to describe the patterns of health, health care and social care consumption.

\section{References}

Äldreberedningen. 1998: Liv till åren: om hälsofrämjande och sjukdomsförebyggande insatser för äldre (Life in old age: On health promotion and prevention of disease for elderly people). Stockholm: Kommentus.

Altvall, H. 2000: Äldre invandrares hälsa (Older migrants' health). Stockholm: Stiftelsen Stockholms läns Äldrecentrum. Rapport 13. Projekt äldre och folkhälsa.

Balarajan, R. 1995-96: Ethnicity and variations in the nation's health. Health-Trends 27, 114-19.

Berg, S. 1996: Aldrandet (Ageing). Stockholm: Förlaget Hagman AB.

Cassel, J. 1974: Psychosocial processes and 'stress': theoretical formulation. International Journal of Health Service Planning, Administration, Evaluation 3, 471-81.

Dalenstam, B. 1999: Inte självklart vilken vård som är bäst för äldre invandrare (It is not self-evident which care is best for older migrants). Vårdfacket 1.

Ekberg, J. 1995: Höj kvalitén på befolkningsstatistiken (Increase the quality of population statistics). Ekonomisk Debatt 23, 329-37.

Ekblad S., Oxenstierna, G. and Akpinar, A. 1998: Invandrarbakgrundens betydelse för sjukvård och socialförsäkring (The influence of migrational background on health care and social insurance). Stockholm: En folkhälsorapport från Stockholms län.

Ekman, S.-L., Heikkilä, K. and Emami, A. 1998: Äldre invandrare $\mathrm{i}$ vård och omsorg (Old migrants in health and social care). Vaird 2, 37-43.

Eliasson Lappalainen, R. and Szebehely, M. 1996: Äldreomsorg, kvalitetssäkring och välfärdspolitik (Elderly care, 
quality assurance and welfare policy). In Palme, J. and Wennemo, I. editors, Generell välfärd (General welfare). Stockholm: Välfärdsprojektet, Socialdepartementets Skriftserie Fakta/kunskap, 87-135.

Eriksson, T. 1996: Äldre invandrare - Kartläggning av kommunernas insatser $i$ Göteborgs och Bohus län samt Hallands län (Old migrants - Description of measures in the local authorities of Gothenburg and the counties of Bohuslän and Halland). Stockholm: Socialstyrelsen.

Gaunt, D. 1996: Etnicitet, åldrande och hälsa: introduktion till ett nytt forskningsfält (Ethnicity, ageing and health: introduction to a new field for research). Socialmedicinsk tidskrift 7-8, 339-46.

Gaunt, D. 2002: Äldre invandrare (Old migrants). In Magnusson, F. editor, Etniska relationer $i$ vaird och omsorg (Ethnic relations in nursing and care). Lund: Studentlitteratur, $61-79$

Hirschman, C., Dewin, J. and Kasinitz, P. (eds). 1999: The handbook of international migration. The American experience. New York: Russel Sage Foundation.

Hjelm, K. 1998: Migration, health and diabetes mellitus. Lund: Department of Community Health Sciences Lund University (dissertation).

Hjelm, K., 1999: Beliefs about health and illness essential for self care practice: a comparison of migrant Yugoslavian and Swedish diabetic females. Journal of Advanced Nursing 30, 1147-59.

Hjelm, K., Apelqvist, J., Nyberg, P., Sundqvist, J. and Isacsson, A. 1997: Health, health care utilization and living conditions in foreign-born diabetic patients in southern Sweden. Journal of Internal Medicine 242, 131-41.

Hjelmskog, S. (ed.) 2000: Hemort Sverige (Sweden, place of residence). Norrköping: Integrationsverket.

Hull, D. 1979: Migration, adaptation and illness: a review. Social Science and Medicine 13, 25-36.

Jylha, M., Guralnik, J.M., Ferucci, L., Jokela, J. and Heikkinen, E. 1998: Is self-rated health comparable across cultures and genders? Journals of Gerontology Series B. Psychological Sciences and Social Sciences May 53, 144-52.

Marmot, M., Adelstein, A. and Bulusu, L. 1984: Immigrant mortality in England and Wales 1980-78. Causes of death by country of birth. Studies on medical and population subjects. London: Office of population censuses and surveys, No. 47, Her Majesty's Stationery Office.

Östergren, P.-O. 2001: Socialt kapital och hälsa (Social capital and health). In Eriksson, C., editor, Sociala skyddsnät och socialt kapital (Social networks and social capital). Stockholm: Forskningsrådsnämnden. Rapport 11, 17-26.

Pudaric, S., Sundquist, J. and Johansson, S.E. 1998: Impaired mobility and impaired working capacity among foreign born people and native born Swedes. Journal of Epidemiology and Community Health 52, 34-40.

2000: Major risk factors for cardiovascular disease in elderly migrants in Sweden. Ethnicity and Health 5, 137-50.
Ronström, O. (ed.) 1996: Vem ska ta hand om de gamla invandrarna? (Who shall take care of old migrants?) Stockholm: Socialtjänsten, FoU-byrån.

SCB. 2001: Statistisk årsbok för Sverige 2001 (Yearbook of statistics for Sweden). Stockholm: Publikationstjänsten SCB.

Selye, H. 1950: The physiology and pathology of exposure to stress. Montreal: ACTA, Inc. Medical Publishers.

SFS Svensk Författningssamling. 1982: Hälso- och sjukvårdslag (The Swedish Health and Medical Services Act). Stockholm.

SFS Svensk Författningssamling. 2001: Socialtjänstlag (The Swedish Social Services Act). Stockholm.

Silveira, E.R.T. 2001: Migration, health and psychological wellbeing in older immigrants in London and Göteborg. Göteborg: Departments of Geriatric Medicine, Social Medicine and Psychiatry, Göteborg University (dissertation).

Singh, G.K. and Siahpush, M. 2001: All-cause and cause specific mortality of immigrants and native born in the United States. American Journal of Public Health 91, 392-99.

Socialstyrelsen. 1991: En mångkulturell äldreomsorg (Multicultural elderly care). Stockholm: Socialstyrelsen.

Socialstyrelsen. 1995: Invandrares hälsa och sociala förhaillanden (Immigrants' health and social conditions). Stockholm: Epidemiologiskt centrum.

Socialstyrelsen. 2000: Anhöriga till äldre invandrare. En fallstudie av anhöriga till äldre utomeuropeiska invandrare utan offentlig äldreomsorg (Relatives of old migrants. A casestudy of relatives of elderly non-European immigrants without public elderly care). Stockholm: Socialstyrelsen.

Songur, W. 2002. Välfärdsstaten, sociala rättigheter och invandrarnas maktresurser. En jämförande studie om äldre invandrare frän Mellanöstern $i$ Stockholm, London och Berlin (The welfare state, social rights and immigrants' power resources. A comparative study of elderly immigrants from the Middle East in Stockholm, London and Berlin). Stockholms Universitet: Statsvetenskapliga Institutionen (dissertation)

Státens offentliga utredningar (SOU). 1984: Invandrar- och minoritetspolitiken (Policy on immigrants and minorities). Slutbetänkande från invandrarpolitiska kommittén. Stockholm: Liber.

Státens Offeatliga utredningar (SOU). 1996: Sverige, mångfalden och framtiden (Sweden, diversity and the future). Slutbetänkande från invandrarpolitiska Kommittén. Stockholm: Nordstedts Tryckeri AB.

Státens Offeatliga utredningar (SOU). 2000: Välfärd, vård och omsorg (Welfare, nursing and social care). Antologi från Kommittén välfärdsbokslut. Stockholm: Nordstedts Tryckeri AB.

Státens Offeatliga utredningar (SOU). 2001: Välfärdsbokslut för 1990-talet (Welfare report for the 1990s). Slutbetänkande av Kommittén välfärdsbokslut. Stockholm: Fritzes.

Strong, K., Trickett, P. and Bhatia, K. 1998: The health of overseas-born Australians, 1994-96. Australian Health Review 21, 124-33. 
Sundqvist, J. and Johansson, S.E. 1997: The influence of country of birth on mortality from all causes and cardiovascular disease in Sweden 1979-1993. International Journal of Epidemiology 26, 279-87.

Waern, E. and Steen, B. 1995: Äldre invandrares hälsa jämförd med svenskars. Största skillnaderna av subjektiv karaktär (Old migrants' health compared to Swedes'. The greatest differences are of subjective character). Läkartidningen 92, 515-18.
Weitoft, G.R., Gullberg, A. and Rosén, M. 1998: En analys av dödligheten i Sverige 1987-94. Ingen överdödlighet för personer födda utanför Norden (An analysis of mortality in Sweden 1987-1994. No excess mortality for people born outside the Nordic countries). Läkartidningen 95, 1277-80, 1282-83.

Westerling, R. 2001: Kan hälso- och sjukvården bidra till en jämlikare hälsa? (Can health care contribute to more equal health?) Social medicinsk tidskrift 3, 231-37. 